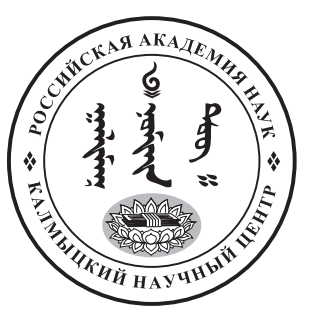

Published in the Russian Federation

Oriental Studies (Previous Name: Bulletin of the Kalmyk Institute

for Humanities of the Russian Academy of Sciences)

Has been issued as a journal since 2008

ISSN: 2619-0990; E-ISSN: 2619-1008

Vol. 14, Is. 1, pp. 134-143, 2021

Journal homepage: https://kigiran.elpub.ru

УДК / UDC 39

DOI: $10.22162 / 2619-0990-2021-53-1-134-143$

\title{
Этнокультурные процессы в Бурятии в 2010-е гг.: проблемы сохранения бурятского языка (по материалам СМИ)
}

\author{
Сэсэгма Гэндэновна Жамбалова ${ }^{1}$
}

${ }^{1}$ Институт монголоведения, буддологии и тибетологии СО РАН (д. 6, ул. Сахьяновой, 670047 Улан-Удэ, Республика Бурятия, Российская Федерация) доктор исторических наук, доцент, ведущий научный сотрудник iD 0000-0002-2672-8126. E-mail: zhambalovas@yandex.ru

(C) КалмНЦ РАН, 2021

(C) Жамбалова С. Г., 2021

Аннотация. Введение. В статье впервые исследуются актуальные проблемы сохранения бурятского языка, важной части этнокультурных процессов в Бурятии на региональных материалах СМИ 2010-х гг. Термин «этнокультурные процессы» понимается как часть современной истории того или иного этноса, реальное выражение развития идей нациестроительства, связанных и с сохранением родного языка. Mатериальы. На основании достоверных источников из СМИ, верифицированных полевыми и литературными материалами, выявлено, что этнокультурные процессы в Республике Бурятия в области сохранения языка титульной нации республики актуальны на всем протяжении постсоветского времени. Результаты. Рассмотрены дискуссионные вопросы: необходимость всеобуча, деятельность Буддийской традиционной сангхи России (БТСР), эффективность освоения субсидий из бюджета РФ, литературный язык и диалекты и др. Предпринимаемые государственные меры, которые на практике нередко носят формальный характер, инициатива общественных организаций, в первую очередь БТСР, способствуя сохранению языка на определенном уровне, не приводят к эффективному результату - процент владеющих бурятским языком падает, что вызвано также сменой поколений. «Перегибы» в вопросе всеобщего изучения языка в школе не безобидны и могут привести к дисбалансу в межнациональных отношениях в регионе. Кроме того, выявляются другие настораживающие тенденции: использование темы для спекулятивных деклараций определенных групп и как фона для проявлений трайбалистских умонастроений, борьба за получение субсидий и др. Для основной массы населения, в том числе части бурятского, сохранение языка в формате обязательного школьного обучения является нежелательной из-за малой эффективности его преподавания и небольшой востребованности в социуме. Bblводыl. Дискуссия, открытая СМИ, вынудила государственные органы Республики Бурятия продолжить ее на «круглых столах» с участием государственных служащих, научных работников, общественности. 
Получены определенные положительные результаты: деятельность БТСР объективно оценена как эффективная, признана необходимость изучения, наряду с литературным языком, его диалектов и говоров, достигнут определенный консенсус между сторонами, который, возможно, позволит выйти этнокультурным процессам на новый уровень.

Ключевые слова: Республика Бурятия, этнокультурные процессы, бурятский язык, сохранение, средства массовой информации, дискуссия, БТСР, литературный язык, диалекты, всеобуч, финансирование, эффективность, трайбализм

Благодарность. Статья подготовлена в рамках государственного задания — проект «Россия и Внутренняя Азия: динамика геополитического, социально-экономического и межкультурного взаимодействия XVII-XXI вв.» (номер госрегистрации: 121031000243-5).

Для цитирования: Жамбалова С. Г. Этнокультурные процессы в Бурятии в 2010-е гг.: проблемы сохранения бурятского языка (по материалам СМИ) // Oriental Studies. 2021. Т. 14. № 1. C. 134-143. DOI: 10.22162/2619-0990-2021-53-1-134-143

\title{
Ethnocultural Processes in Buryatia, 2010s: Issues of Buryat Language Preservation (A Study of Mass Media Materials)
}

\section{Sesegma G. Zhambalova ${ }^{1}$}

${ }^{1}$ Institute for Mongolian, Buddhist and Tibetan Studies, Siberian Branch of the RAS (6, Sakhyanova St., Ulan-Ude 670047, Russian Federation)

Dr. Sc. (History), Associate Professor, Leading Research Associate

iD 0000-0002-2672-8126. E-mail: zhambalovas@yandex.ru

(C) KalmSC RAS, 2021

(C) Zhambalova S. G., 2021

\begin{abstract}
Introduction. The article newly examines regional mass media materials of the 2010s for current problems of Buryat language preservation, the latter being an important element of Buryatia's ethnocultural processes. The term 'ethnocultural processes' is understood as a part of contemporary Buryat history, a true expression to denote the development of nation building ideas, including ones related to native language preservation. Materials. The paper considers a number of issues, namely: the need for universal language learning, activities by the Buddhist Traditional Sangha of Russia (BTSR), efficiency of application of federal budget subsidies, literary language and dialects, etc. The reliable media sources confirmed by field and literary materials attest to that ethnocultural processes in Buryatia pertaining to the preservation of the regional titular nation's language remain relevant throughout the post-Soviet era. Results. The Government's measures (often essentially formal), initiatives of public organizations (primarily those by BTSR) do contribute to the preservation of the language at a certain level, but yield no transformative results - the share of fluent speakers decreases, which is also caused by the succession of generations. The extremities of obliging all pupils to learn the language are not that harmless and can lead to an imbalance in interethnic relations in the region. Other alarming trends discussed are as follows: the use of the topic for speculative declarations by certain groups and as a background for manifestations of tribalistic attitudes, struggles for subsidies, etc. For the bulk of the population, including some Buryats, language preservation through compulsory schooling is undesirable for its low teaching efficiency and lack of usage prospects determined by insufficient demand in society. Conclusions. The discussion initiated by the mass media forced government agencies of the republic to continue the former at round tables with the participation of officials, scientists, and the public. That resulted in certain positive results, namely: efforts of BTSR were objectively assessed as efficient, and the need to study dialects and subdialects along with the literary language was recognized, the latter establishing a certain consensus between the parties, which shall possibly promote the ethnocultural processes to a new level.
\end{abstract}


Keywords: Republic of Buryatia, Buryats, ethnocultural processes, Buryat language, problem, preservation, mass media, discussion, BTSR, literary language, dialects, universal education, financing, efficiency, tribalism

Acknowledgements. The reported study was funded by government subsidy — project 'Russia and Inner Asia: Dynamics of Geopolitical, Socioeconomic and Cross-Cultural Interactions of $17^{\text {th }}-21^{\text {st }}$ centuries' (state reg. no. 121031000243-5).

For citation: Zhambalova S. G. Ethnocultural Processes in Buryatia, 2010s: Issues of Buryat Language Preservation (A Study of Mass Media Materials). Oriental Studies. 2021. Vol. 14(1): 134-143. (In Russ.). DOI: 10.22162/2619-0990-2021-53-1-134-143

\section{है}

\section{Введение}

Цель статьи - рассмотреть на региональных материалах СМИ последнего десятилетия проблемы сохранения бурятского языка как важной грани происходящих в Республике Бурятия (РБ) этнокультурных процессов. Они верифицированы материалами российских СМИ, полевыми материалами автора 2016-2019 гг. и литературными источниками. Термин «этнокультурные процессы» в РБ используется в определении Д. Д. Амоголоновой как реальное выражение «развития идей нациестроительства, связанных с консолидацией всех бурят и территорий их проживания, возвращением исторической и культурной памяти, повышением статуса бурятского языка, возрождением традиционных форм хозяйствования» [Амоголонова 2009: 3].

Объем статьи позволяет только отметить, что тема изучается в РФ, а также с недавних пор филологами-бурятоведами и бурятскими социологами, на некоторые их работы имеются ссылки в статье. На материалах региональной периодической печати до 2005 г. данные вопросы исследовались Д. Д. Амоголоновой [Амоголонова 2008]. Научных статей в предложенном здесь ракурсе нет.

Проблема сохранения национальных языков в полиэтничной РФ, а особенно для сибирских этносов, одна из актуальных. Всплеск этнокультурных процессов в РБ пришелся и на осень 2019 г.: протестное настроение общественности и отдельных граждан, обнародованное в публикациях, было вызвано государственными мерами по акцентированию добровольности изучения национального языка республик РФ. Каждая публикация сопровождалась мно- гочисленными комментариями и обсуждениями. Государственные органы были вынуждены отреагировать и провести ряд заседаний, в том числе в формате «круглого стола». В публикации от 25 декабря 2019 г. так описывают ситуацию: «... обвинения интеллигенции в геноциде бурятского народа. Публичные отповеди главой буддистов России руководства республики из-за нежелания принимать меры по спасению бурятского языка, сел и традиционного уклада жизни бурят. < ..> Федеральные СМИ сообщили, что преподавание бурятского языка в скором времени возобновится во всех школах республики. < ..> Общественная палата РБ должна была сконсолидировать народ в деле сохранения языка. Но фактически попытки разделения бурят на западных и восточных, говорящих и не говорящих на бурятском языке, в полной мере продолжились и на ее дискуссионной площадке» [Интогарова 2019].

Для РБ, где проживают более 100 национальностей, а государственными являются русский и бурятский, характерна несбалансированная социально-коммуникативная система с набором неравнозначных в функциональном отношении языков: во всех сферах общения применяются два языка, русский и бурятский. Объем общественных функций бурятского не значителен, а сфер его интенсивного употребления немного [Дырхеева 2018: 304]. Причина беспокойства общественности - сокращение объема социального функционирования языка в повседневной жизни общества и семьи, увеличение темпа реэтнизации этносознания и этноязыка. Свидетельствуют об этом данные переписей: в 2002 г. в РБ родным языком владели 81,4 \% бурят, а в 2010 г. - 
43,6 \%. Опрос в 2018 г. 1225 старшеклассников показал: 38,4 \% хорошо владели языком, 35,6 \% - плохо, 26,0 \% - не владели [Дырхеева 2019: 14]. Очевидно, ухудшение показателей обусловлено сменой поколений, а межпоколенческой трансляции знания родного языка не произошло.

\section{Всеобуч бурятского языка?}

В РФ сохранение языков всех народов страны гарантируется законом и является государственной задачей. В апреле 2018 г. в ГД РФ внесен проект поправок в закон «Об образовании в РФ», устанавливающий преподавание государственных языков субъектов РФ на добровольной основе, а изучение родных языков с учетом потребностей школьников и их родителей. Еще не рассмотренный в первом чтении законопроект вызвал большой резонанс [Дашковская 2018].

В СМИ писали: «На федеральном уровне взят курс на отмену обязательного изучения нерусских языков в школах национальных республик РФ. Это вызвало резонанс в обществе. Некоторые эксперты и национальные активисты посчитали, что такие меры ударят по перспективам развития не только отдельных языков, но и наций в целом» [Когда в России 2018]. На самом деле поправка, одобренная в окончательной редакции ГД РФ, не задевает национальные интересы народов, оставляя свободный выбор родного языка родителями школьника. ГД РФ поддержала инициативу создания федерального фонда поддержки родных языков для научного изучения языков, для подготовки учебников и учебных пособий [Принят закон 2018].

Вторая, не менее болезненная, сторона вопроса, обсуждаемых в социуме и СМИ: нужно ли доминирующему численно небурятскому населению (70 \%, бурят - $30 \%)$ изучать язык титульной нации республики в обязательном порядке? Опираясь на российские законы, можно утверждать, проблема искусственно создана усилиями республиканских государственных органов, общественными объединениями и населением, поэтому сложилась такая обстановка: в законе требования нет, а на практике оно есть.

В 2019 г. из 472 школ РБ бурятский язык изучают в 453 (69 047 чел., 49,7 \%), в 19 не изучают; в 99 как родной изучают 8279 детей $(21 \%)$, в 354 как государственный (60 768 учащихся, 43,7 \%) [Цыренов 2019: $72]$.

С 2017 по 2019 гг. число изучающих язык сократилось на два процента из-за добровольности изучения и возросшей языковой нагрузки на учеников по изучению второго иностранного языка как обязательного [Эффективность 2019]. Такой сдвиг не устраивает некоторых бурятских активистов, они требуют всеобуча, когда его должны изучать все.

Требование всеобуча приводит к протестным настроениям родителей, которое подхватила Коммунистическая партия Российской Федерации РБ. В декабре 2013 г. прошел сбор подписей об отмене обязательного изучения бурятского языка. В петиции отмечается, что, несмотря на Закон о языках РБ, всех детей обязывают изучать бурятский язык. Далее следует: «Во многом это произошло потому, что родители элементарно не знали о праве добровольного изучения языка $<\ldots>$ они часто были откровенно дезинформированы и введены в заблуждение $<\ldots>$ Многие боятся поднимать этот вопрос из страха навредить детям <...> Мы уважаем достойное стремление бурятского народа к сохранению и развитию своего языка и культуры, но делать надо это не путем силы, а другими средствами и методами» [Добровольное изучение 2013].

Петиция довольно достоверно отражает ситуацию. Во время полевых исследований выявлено: бурятский язык изучают согласно разработанным Министерством образования и науки РБ методическим рекомендациям. Например, в 2015-2016 учебном году предложено четыре варианта образовательных программ: для школ с русским контингентом с пятидневным регламентом, изучающих язык как государственный; для школ с таким же регламентом, где бурятский родной; рекомендации для школ с шестидневным регламентом, где бурятский - государственный язык, а бурятский родной. Объем изучения языка нередко корректируется министерством. Публикация в СМИ дает такие данные: в 2019 г по программе родной язык предусмотрено пять уроков в неделю, по ней в г. Улан-Удэ работает Республиканский бурятский национальный лицей-интернат № 1, а в республике - не- 
сколько сельских школ; по второй программе - большинство школ, на эти уроки отводится два часа в неделю [Эффективность 2019].

Опрос учителей и родителей показывает, что язык изучают на добровольно-принудительной основе. По полевым материалам, в 2015 г. руководство отдельных школ моноэтничных русских поселений привлекали к административной ответственности за отсутствие в учебном плане программы по изучению языка. В 2016 г. рекомендовано на общешкольном родительском собрании голосовать «за» или «против» изучения языка. В одной школе русского села родители вместо голосования заполняли анкеты. Небольшим большинством язык включен в обязательную учебную программу.

Язык изучают и в полиэтничных поселениях, и в моноэтничных русских и русских старообрядческих (семейских). В 2017 г. во время полевой работы в семейском селе Хасуртай Хоринского района РБ было записано со слов директора МБОУ «Хасуртайская СОШ»: «Во всех школах республики должен вестись бурятский язык, но у нас нет учителя. Однако эти часы мы используем так: ведем на русском языке предмет „Бурятская литература“, а в девятом классе ведем на русском языке „Историю Бурятии“» [ПМА 2016-2017]. Мозаичная картина высвечивается из слов другой учительницы: «У нас в Заиграевском районе из 31 школы в 18 изучают бурятский язык. И даже в Онохое, где почти не проживают буряты. Это не Бичурский район, где отказались от изучения второго государственного языка» [Ян 2013].

Поэтому при общественном обсуждении республиканского законопроекта об образовании наиболее резонансным оказался вопрос всеобуча бурятского языка вопреки российским законам. Перехлест наблюдался не только в РБ. Например, в Республике Татарстан отказы от изучения языка писали русскоязычные и некоторые татарские семьи. Все это привело к появлению в 2018 г. подзаконного акта, корректирующего закон о национальном языке в РФ. 20 июля 2017 г. в Йошкар-Оле президент РФ В. В. Путин отмечал, что «русский язык для нас — язык государственный, язык межнационального общения, <..> он естественный духовный каркас всей нашей многонациональной страны $<\ldots>$ Языки народов России — это тоже неотъемлемая часть самобытной культуры народов России. Изучать эти языки гарантированное Конституцией право, право добровольное. Заставлять человека учить язык, который для него родным не является, так же недопустимо, как и снижать уровень и время преподавания русского» [Дашковская 2018]. Прокуратурой Республики Татарстан проверено полторы тысячи школ, были уволены учителя татарского языка, а другие были переквалифицированы в преподавателей родного языка и литературы» [Дашковская 2018].

Федеральный закон от 29.12.2012 № 273-Ф3 (ред. от 02.12.2019) «Об образовании в Российской Федерации» гарантирует преподавание и изучение государственных языков субъектов РФ, свободный выбор языка образования, родного языка, в том числе русского как родного языка, государственных языков субъектов РФ, осуществляется по заявлениям родителей [Ф3 об образовании 2012].

В этих условиях государственные органы РБ и бурятские активисты продолжают бороться за 100-процентный охват школьников всех национальностей. Может ли это способствовать сохранению бурятского языка? Депутаты Народного Хурала РБ определяют эффективность субсидий на сохранение бурятского языка количеством его изучающих. И. В. Марковец оценил эффективность реализации программы закона «О мерах поддержки бурятского языка как государственного языка РБ» как «практически нулевая». Он сказал в 2019 г.: «Почти 150 млн рублей вложено, для учителей бурятского языка предусмотрена финансовая поддержка, но при всем при этом статистика показывает, что количество тех, кто изучает бурятский язык, не увеличивается, а даже снижается. Эффективность тогда этих средств в чем? Помимо работы с детьми, какая ведется работа с родителями? Чем вы пытались их заинтересовать? Денег-то тратим немало» [Эффективность 2019]. Другой депутат предлагает: «в качестве мотивации поощрять школы, которые увеличивают количество учеников, изучающих бурятский язык» [Эффективность 2019]. Такой подход противоречит российским законам и создает условия для искусственного ажиотажа вокруг проблемы. 
Ситуацию объективно иллюстрирует публикация А. Яна в 2013 г., написанная по материалам конференции по проблемам сохранения бурятского языка «Ерээдуй сагай буряад хэлэнэй урасхал», проведенной БТСР. Депутат Народного Хурала РБ Ц. Б. Батуев показал реальную картину отношения к изучению языка в разных поселениях региона. В районном центре Кижинга, где превалирует бурятское население, директора школ упрекают депутатов в «умирании» языка. В пгт. Наушки родители-военнослужащие против его изучения. Рядом, в русском с. Усть-Кяхта, жалуются на шестидневку из-за бурятского. В г. Кяхта в гимназии изучают русский, бурятский, английский, китайский. В бурятском с. Корсаково Кабанского района бурятский учат с 1 по 11 класс [Ян 2013].

Проблемы методики и технологии обучения - один из обсуждаемых в народе и поднимаемых в СМИ вопросов. Общепризнано отсутствие современных прогрессивных методик и технологий преподавания бурятского языка, современных учебников, а также детских книг, мультфильмов, развивающих игр и пр. В то время как речь идет об обучении языку с нуля детей, чья повседневная жизнь проходит в другой доминантной языковой среде, чьи родители в основном не знают язык. Поэтому язык надо преподавать по современным методикам обучения иностранному языку. Публикации свидетельствуют об определенных шагах в данном направлении. Но насколько они эффективны? В октябре 2006 г. состоялась презентация электронного учебника бурятского языка, «первого в России проекта, позволяющего сохранить вымирающие языки народов в многонациональной стране. Поэтому первый диск будет отправлен в подарок президенту России как пример использования современных технологий для сохранения любого языка» [Уникальный учебник 2006]. Учебно-методический комплекс содержит 1390 проверочных и контрольных упражнений, 59 диктантов, 54 интерактивные таблицы, теоретические материалы и словарь грамматических терминов, «Ларец изящных изречений», раздел «Из опыта работы учителей», 14 словарей [Уникальный учебник 2006].
В Бурятии работает несколько специальных методических бюджетных учреждений по сохранению и развитию языка. Центр сохранения и развития бурятского языка со штатом 11 человек создан 28 августа 2015 г. при Бурятском государственном университете. В штате директор, замдиректора, девять сотрудников на должностях методистов. B Elibrary из них зарегистрировано четверо, на двоих числится пять статей по теме. Это также ГБУ РЦ «Бэлиг», созданное в 2000 г. в рамках правительственной программы по сохранению и развитию бурятского языка. Сотрудники проводят семинары-практикумы для учителей по апробации новых учебных комплектов, что обусловлено ее основной деятельностью - изданием книг, брошюр, рекламных буклетов, словарей и энциклопедий [РЦ «Бэлиг» 2002]. В январе 2019 г. при нем создан Республиканский центр по развитию бурятского языка «с целью совершенствования работы по сохранению и развитию бурятского языка» [В Бурятии создан 2019] для координирования направлений по изучению языка в школах, созданию электронных приложений и словарей, обобщению опыта педагогов, разработке программ и методических пособий, реализации трехстороннего соглашения между министерствами образования РБ, Иркутской области и Забайкальского края, где исконно проживают буряты, о создании единого образовательного пространства по преподаванию языка, мониторинга исполнения закона РБ «О мерах поддержки бурятского языка как государственного языка РБ» в части вопросов, входящих в компетенцию образовательного ведомства [В Бурятии создан 2019].

6 мая 2017 г. опубликована информация: «впервые в новейшей истории учебники по бурятскому языку вошли в федеральный школьный перечень» [Ульянова 2017]. Книги выпускаются по двум программам: для национальных школ, где бурятский изучают как родной язык, и для начинающих. Спрос имеют учебники для второй группы, школ первого типа мало. В планах к 2020 г. обеспечить всех учеников республики с 1-го по 11-й класс учебниками по обеим программам. Учебники прошли научно-педагогическую экспертизу в РАН и этно-культурно-общественную региональную экспертизу в педагогическом коллед- 
же [Ульянова 2017]. «Букварь» (Узэглэл) и «Бурятский язык» (Буряад хэлэн) вошли в реестр учебников, одобренных на федеральном уровне.

Деятельность БТСР по сохранению бурятского языка вызвала наибольшую дискуссию в СМИ - достаточно публикаций с диаметрально противоположными мнениями, каждая сопровождается шквалом читательских комментариев. БТСР организует мероприятия с целью повышения ценности языка в социально-культурной иерархии человеческих ценностей бурятского общества: издание диалектных словарей, проведение конкурсов, написание диктантов и т. д. Однако немало журналистов и общественников считает, что инициативы буддийских священнослужителей в данной области идут вразрез с задачами правительства РБ. Согласно публикациям, создается впечатление наличия двух параллельных линий движения: одна государственная, другая - БТСР. На практике языковая политика БТСР вписана в контекст ее общей концепции по сохранению и возрождению традиционной этничности и традиционализма у народа: она, как показывают нижеследующие материалы, рациональна и может способствовать сохранению языка как средства повседневного общения бурят в семье и в обществе.

Интервью дид хамбо ламы БТСР Д. Очирова от 23 февраля 2016 г. содержит, как показывает верификация с другими документами, достоверную информацию. В материале «Информ-полиса» говорится, что в 2011 г. впервые за 90 лет истории Бурятии заработала государственная программа «Сохранение и развитие бурятского языка в РБ». В 2015 г. на нее выделено 36 млн 350 тыс. руб., распределенные так: 20 млн 770 тыс. - министерству образования и науки; 9 млн 870 тыс. - администрации главы и правительства; 5 млн 710 тыс. министерству культуры. Минобразования распределило миллионы, как следует из интервью, следующим образом: 950 тыс. руб. выделили для мониторинга уровня владения языком учащихся 1-11 классов, когда и так понятно, что народ плохо владеет родным языком; на издание литературы на бурятском языке для библиотек ушло 5 млн 590 тыс. руб. Из 6 млн 500 тыс. руб. 4 млн 200 тыс. руб. потратили на издание 300 экзем- пляров 15-томного сборника «Байгалай толон», а 922,5 тыс. руб. — на приобретение портретов писателей и ученых Бурятии. Таким образом расходуют средства в то время, когда нет изданий детских сказок русских и бурятских классиков на бурятском языке, мультфильмов и компьютерных игр [Ян 2016]. Далее в интервью говорится: «Теперь обратите внимание на статью расходов „Создание условий для изучения бурятского языка“. Выделено 7 млн 480 тыс. Из них 3 млн 600 тыс. направлено на создание всего двух кабинетов бурятского языка! Спасет ли это нас от незнания родного языка?» [Ян 2016]. Д. Очиров также отметил, что БТСР с июня 2014 г. взяла на себя организацию в стенах Буддийского университета «Даши Чойнхорлин» всебурятского конкурса «Эхэ хэлэн - манай баялиг» («Материнский язык - наше богатство») [Ян 2016]. В 2015 г. получена лицензия на вещание первого в истории бурятского FM-радио на бурятских диалектах [Ян 2016]. Общий объем передачи на бурятском языке на всех каналах телевидения составляет менее $1 \%$ [Дырхеева 2019: 15].

\section{Диалект vs литературный язык?}

Наиболее парадоксальной в силу самой постановки вопроса является одна из тем дискуссии - проблема «диалект/литературный язык». Б. Д. Цыренов, отмечая, что «бурятский язык многодиалектный - это признанный факт», выделяет 4 бурятских наречия, каждое со своими говорами [Цыренов 2012: 176].

Инициатива БТСР по изданию диалектных словарей воспринята многими как действие против единства бурятского народа. В публикации от 26 сентября 2019 г. пишется, что «противники литературного бурятского языка выступили против единства нации $<\ldots .>$. Литературный бурятский язык - результат политики компромиссов. Поэтому те, кто подменяет понятия и годами ведет яростный джихад против „хоринского=литературного“, в сущности, воюет против всей идеи компромисса между диалектами, племенами, кланами, против идеи единства бурятской нации» [Цыбикдоржиев 2019]. Безусловно, здесь наличествуют некие трайбалистские настроения. В результате дискуссии правительством РБ поддержана идея издания словарей диалектов [Соктуева 2019]. 


\section{Выводы}

В статье впервые исследуются актуальные проблемы сохранения бурятского языка как важной грани этнокультурных процессов в Бурятии на региональных материалах СМИ 2010-х гг. На основании достоверных источников из СМИ, верифицированных материалами федеральных СМИ, полевыми и литературными материалами, выявлено, что этнокультурные процессы в РБ в области сохранения языка титульной нации республики актуальны на всем протяжении постсоветского времени. Предпринимаемые государственные меры, инициатива общественных организаций, в первую очередь БТСР, способствуя сохранению языка на определенном уровне, не приводят к эффективному результату — процент владеющих языком падает, что вызвано также сменой поколений. Перегибы в вопросе всеобщего изучения языка в школе не безобидны и могут привести к дисбалансу в межна-

\section{Полевые материалы автора}

ПМА 2016-2017 - Полевые материалы автора 2016-2017 гг. Экспедиционные этнографические исследования в РБ в рамках гранта JSPS по проекту «Исторические и этнографические исследования по российским и зарубежным старообрядцам».

\section{Литература}

Амоголонова 2008 - Амоголонова Д. Д. Современная бурятская этносфера: дискурсы, парадигмы, социокультурные практики. Улан-Удэ: Изд-во Бурят. гос. ун-та, 2008. 292 c.

Амоголонова 2009 - Амоголонова Д. Д. Бурятские этнокультурные процессы в условиях трансформации российского общества (1990-2000-е гг.): автореф. дисс. ... д-ра ист. наук. Улан-Удэ, 2009. 50 с.

В Бурятии создан 2019 - В Бурятии создан центр по развитию бурятского языка [электронный ресурс] // Новости. Министерство образования и науки Республики Бурятия. 25 января 2019. URL: https://egovburyatia.ru/minobr/press_center/news/detail. php?ID=28070 (дата обращения: 07.08.2020).

Дашковская 2018 - Дашковская О. Изучение национальных языков в школе: добровольно или принудительно? [электронный pecypc] // Вести образования. Тема дня. Качество образования. 29 мая 2018. URL: циональных отношениях в регионе. Также выявляются другие настораживающие тенденции: использование темы для спекулятивных деклараций определенных групп и как фона для проявлений трайбалистских умонастроений, борьба за получение субсидий и др. Для основной массы населения, в том числе части бурятского, сохранение языка в формате обязательного школьного обучения является нежелательной из-за малой эффективности его преподавания и малой востребованности в социуме. Дискуссия, открытая СМИ, вынудила государственные органы РБ заострить внимание на вопросе. В итоге получены положительные результаты: деятельность БТСР оценена как эффективная, признана необходимость изучения, наряду с литературным языком, его диалектов и говоров, достигнут определенный консенсус между сторонами, который, возможно, позволит выйти этнокультурным процессам на новый уровень.

\section{Author's Field Data}

Ethnographic materials of 2016-2017 expeditions to the Republic of Belarus, JSPS grant project 'Historical and Ethnographic Research on Russian and Foreign Old Believers'.

https://vogazeta.ru/articles/2018/5/29/quality_ of_education/3438-izuchenie_natsionalnyh_ yazykov_v_shkole_dobrovolno_ili_ prinuditelno (дата обращения: 23.12.2019).

Добровольное изучение 2013 - Добровольное изучение бурятского языка в республике Бурятия [электронный ресурс] // Открытый город. 9 декабря 2013 г. URL: // https://www. opentown.org/news/25234/ (дата обращения: 07.08.2020).

Дырхеева 2018 - Дырхеева Г. А. Языковая ситуация в Республике Бурятия // Мир Большого Алтая. 2018. Т. 4. № 2. С. 302-320.

Дырхеева 2019 - Дырхеева Г. А. Бурятский язык десять лет спустя: современные проблемы функционирования и перспективы развития // Языки в полиэтническом государстве: развитие, планирование, прогнозирование. Междунар. конф. (г. Улан-У дэ, Горячинск, 1-4 июля 2019 г.): доклады и сообщения / отв. Г. А. Дырхеева, А. Н. Биткеева, С. В. Кириленко, Б. Д. Цыренов. Улан-Удэ: 2019. С. 14-16. 
Интогарова 2019 - Интогарова С. Бурятская чиновничья синекура приказала долго жить [электронный ресурс] // Московский комсомолец в Улан-Удэ. 25.12.2019. URL: https:ulan.mk.ru/politics/2019/12/25/ buryatskaya-chinovnichya-sinekura-prikazaladolgo-zhit.html (дата обращения: 23.01.2020).

Когда в России 2018 - Когда в России вымрут все языки, кроме русского? За и против [электронный ресурс] // Алиф-ТВ. Интервью с М. Осадчим, проректором Института русского языка им. А. Пушкина. 20.04.2018. URL: https://alif.tv/kogda-v-rossii-vymrut-vseyazyki-krome-russkogo-za-i-protiv/ (дата обращения: 07.08.2020).

Принят закон 2018 - Принят закон об изучении родных языков [электронный ресурс] // Новости. Государственная дума ФС PФ. 25.07.2018. URL: http://duma.gov.ru/ news/27720/ (дата обращения: 07.08.2020).

РЦ «Бэлиг» 2002 — ГБУ РЦ «Бэлиг» по поддержке изучения национальных языков и иных предметов этнокультурной направленности [электронный ресурс] // Rusprofile. Выписка из ЕГРЮЛ. URL: https://www.rusprofile.ru/ id/1209221 (дата обращения: 07.07.2020).

Соктуева 2019 - Соктуева H. В Улан-Удэ издали словари улюнских и харлунских бурят [электронный ресурс] // Информ-полис. 12.02.2019. URL: https://www. infpol.ru/196711-v-ulan-ude-izdali-slovariulyunskikh-i-kharlunskikh-buryat/ (дата обращения: 23.01.2020).

Ульянова 2017 - Ульянова Л. Учебники по бурятскому языку вышли на федеральный уровень [электронный ресурс] // Газета «Номер один». 06.05.2017. URL: https://gazeta-n1.ru/ news/50495/ (дата обращения: 07.07.2020).

Уникальный учебник 2006 - Уникальный учебник бурятского языка подарят Путину [электронный ресурс] // Информ-полис онлайн. 24.10.2006. URL: https://www.infpol. ru/169144-unikalnyy-uchebnik-buryatskogoyazyka-podaryat-putinu/ (дата обращения: 07.07.2020).

\section{References}

Amogolonova D. D. Buryat Ethnocultural Processes in the Context of Transformed Russian Society, 1990s-2000s. Dr. Sc. (history) thesis abstract. Ulan-Ude, 2009. 50 p. (In Russ.)

Amogolonova D. D. Contemporary Buryat Ethnosphere: Discourses, Paradigms, Sociocultural Practices. Ulan-Ude: Buryat State University, 2008. 292 p. (In Russ.)
Ф3 об образовании 2012 - Федеральный закон от 29.12.2012 N 273-Ф3 (ред. от 02.12.2019) «Об образовании в Российской Федерации» [электронный ресурс] // URL: http:// www.consultant.ru/document/cons_doc_ LAW_140174/ (дата обращения: 07.07.2020). Цыбикдоржиев 2019 - Цыббкдоржиев Д. Разрубить и уничтожить. Почему противники литературного бурятского языка выступили против единства нации [электронный ресурс] // Asia Russia daily (ARD). 26 сентября 2019 г. URL: http://asiarussia.ru/ articles/22519/ (дата обращения: 07.07.2020).

Цыренов 2012 - Цыренов Б. Д.. Проблемы составления бурятского диалектического словаря // Вестник Бурятского научного центра Сибирского отделения Российской академии наук. 2012. № 1 (5). С. 176-181.

Цыренов 2019 - Цыренов Б. Д. Бурятский язык: вопросы выживания // Языки в полиэтническом государстве: развитие, планирование, прогнозирование. Междунар. конф. (г. Улан-Удэ, Горячинск, 1-4 июля 2019 г.): доклады и сообщения / отв. ред. Г. А. Дырхеева, А. Н. Биткеева, С. В. Кириленко, Б. Д. Цыренов. Улан-Удэ: Изд-во БНЦ СО РАН, 2019. С. 71-74.

Эффективность 2019 - Эффективность бюджетной поддержки бурятского языка «почти нулевая» [электронный ресурс] // Газета «Номер один». 19.12.2019. URL: https:// gazeta-n1.ru/news/society/81388/ (дата обращения: 13.01.2020).

Ян 2013 - Ян Андрей. «Плач» по бурятскому языку [электронный ресурс] // Информ-полис онлайн. 12.11.2013. URL: https://www. infpol.ru/148249-plach-po-buryatskomuyazyku/ (дата обращения: 07.07.2020).

Ян 2016-Ян Андрей. Дид Хамбо Сангхи России: «Состояние бурятского языка вызывает тревогу» [электронный ресурс] // Информ-полис онлайн. 23.02.2016. URL: https://www. infpol.ru/112234-did-khambo-sangkhi-rossiisostoyanie-buryatskogo-yazyka-vyzyvaettrevogu/ (дата обращения: 07.07.2020).

Belig State-Funded Republican Center for Learning / Teaching Local Languages and Related Ethnocultural Disciplines. On: Rusprofile. Website. State Register Extract. Available at: https:// www.rusprofile.ru/id/1209221 (accessed: July 7, 2020). (In Russ.)

Budgetary support of Buryat language: efficiency tends to zero. On: Gazeta Nomer odin. Newspaper's website. Posted on December 19, 2019. 
Available at: https:/gazeta-n1.ru/news/society/81388/ (accessed: January 13, 2020). (In Russ.)

Buryat language development center established in Buryatia. On: Ministry of Education and Science of the Republic of Buryatia. Website. News Feed. Posted on January 25, 2019. Available at: https://egov-buryatia.ru/minobr/press center/news/detail.php?ID=28070 (accessed August 7, 2020). (In Russ.)

Dashkovskaya O. Learning local languages at school: voluntarily or forcibly? On: Vesti obrazovaniya (News of Education). Online media outlet. Posted on May 29, 2018. Available at: https:/vogazeta.ru/articles/2018/5/29/quality_ of_education/3438-izuchenie_natsionalnyh_ yazykov_v_shkole_dobrovolno_ili_prinuditelno (accessed: December 23, 2019). (In Russ.)

Dyrkheeva G. A. The Buryat language ten years later: contemporary problems of functioning and prospects of development. In: Dyrkheeva G. A., Bitkeeva A. N., Kirilenko S. V., Tsyrenov B. D. (eds.) Languages in a Polyethnic State - Development, Planning, Forecasting. Conference Proceedings (Ulan-Ude, Goryachinsk; July 1-4, 2019). Ulan-Ude, 2019. Pp. 14-16. (In Russ.)

Dyrkheeva G. A. The language situation in Buryat Republic. World of the Great Altai. 2018. Vol. 4. No. 2. Pp. 302-320. (In Russ.)

Federal Law of 29 December 2012 No. 273-Ф3 (as amended on December 2, 2019) On Education in the Russian Federation. Available at: http://www.consultant.ru/document/cons_doc LAW_140174/ (accessed: July 7, 2020). (In Russ.)

Intogarova S. Buryat bureaucratic sinecure on last legs. On: Moskovskiy Komsomolets v UlanUde. Newspaper's website. Posted on December 25, 2019. Available at: https:ulan. mk.ru/politics/2019/12/25/buryatskaya-chinovnichya-sinekura-prikazala-dolgo-zhit.html (accessed: January 23, 2020). (In Russ.)

Law on learning / teaching of native languages passed. On: The State Duma. Website. News Feed. Posted on July 25, 2018. Available at: http://duma.gov.ru/news/27720/ (accessed: August 7, 2020). (In Russ.)

Soktueva N. Dictionaries of Ulyun and Kharlun Buryat dialects published in Ulan-Ude. On: Inform-polis. Online media outlet. Posted on February 12, 2019. Available at: https://www. infpol.ru/196711-v-ulan-ude-izdali-slovariulyunskikh-i-kharlunskikh-buryat/ (accessed: January 23, 2020). (In Russ.)
Tsybikdorzhiev D. Be it divided and eradicated: Why opponents of literary Buryat argue against ethnic unity. On: Asia Russia daily (ARD). Online media outlet. Posted on September 26, 2019. Available at: http://asiarussia.ru/articles/22519/ (accessed: July 7, 2020). (In Russ.)

Tsyrenov B. D. Buryat languages: issues of survival. In: Dyrkheeva G. A., Bitkeeva A. N., Kirilenko S. V., Tsyrenov B. D. (eds.) Languages in a Polyethnic State - Development, Planning, Forecasting. Conference Proceedings (UlanUde, Goryachinsk; July 1-4, 2019). Ulan-Ude, 2019. Pp. 71-74. (In Russ.)

Tsyrenov B. D. The problems of the compilation of the Buryat dialectological dictionary. Bulletin of the Buryat Scientific Center of the Siberian Branch of the Russian Academy of Sciences. 2012. No. 1 (5). Pp. 176-181. (In Russ.)

Ulyanova L. Buryat language textbooks promoted onto federal level. On: Gazeta Nomer odin. Newspaper's website. Posted on May 6, 2017. Available at: https://gazeta-n1.ru/news/50495/ (accessed: July 7, 2020). (In Russ.)

Unique Buryat language textbook shall be presented to Putin. On: Inform-polis. Online media outlet. Posted on October 24, 2006. Available at: https://www.infpol.ru/169144-unikalnyy-uchebnik-buryatskogo-yazyka-podaryat-putinu/ (accessed: July 7, 2020). (In Russ.)

Voluntary learning of Buryat in the Republic of Buryatia. On: Otkrytyi gorod (Open Town). Online media outlet. Posted on December 9, 2013. Available at: // https://www.opentown. org/news/25234/ (accessed: August 7, 2020). (In Russ.)

When shall all minority languages of Russia become extinct? Pro et contra. On: Alif-TV. Website. Interview with M. Osadchy, Vice Principal at the Pushkin State Russian Language Institute. Posted on April 20, 2018. Available at: https:// alif.tv/kogda-v-rossii-vymrut-vse-yazyki-krome-russkogo-za-i-protiv/ (accessed: August 7, 2020). (In Russ.)

Yan A. 'Lamentations' over Buryat language. On: Inform-polis. Online media outlet. Posted on November 12, 2013. Available at: https://www. infpol.ru/148249-plach-po-buryatskomu-yazyku/ (accessed: July 7, 2020). (In Russ.)

Yan A. Did Khambo of Russia's Sangha: 'Currents conditions of Buryat language arouse concern'. On: Inform-polis. Online media outlet. Posted on February 23, 2016. Available at: https://www.infpol.ru/112234-did-khambo-sangkhi-rossii-sostoyanie-buryatskogo-yazyka-vyzyvaet-trevogu/ (accessed: July 7, 2020). (In Russ.) 